\title{
ISO 14001 Environmental Management Systems Certification, Firm Characteristics and Performance of Certified Firms in Nairobi County, Kenya
}

\author{
Elizabeth Wagithi Wamai ${ }^{1} \&$ James M.Kilika ${ }^{2}$ \\ ${ }^{1}$ Quality Management Systems Representative, Kapa Oil Refineries, Kenya \\ ${ }^{2}$ Department of Business Administration, Kenyatta University, Kenya \\ Correspondence: James M.Kilika, PhD, Lecturer, Department of Business Administration, Kenyatta University, \\ Kenya.
}

Received: August 30, 2016

Accepted: October 7, 2016

Online Published: October 28, 2016

doi:10.5430/jms.v7n4p30

URL: http://dx.doi.org/10.5430/jms.v7n4p30

\begin{abstract}
Rising environmental concerns and stakeholder demands for demonstration of environmental responsibility by firms has culminated in widespread adoption of Environmental Management Systems (EMSs), with the framework based on the ISO 14001 standard being the most popular. One question that has dominated research is how ISO 14001 EMS certification contributes to firm performance. Studies on this question have largely focused on countries outside the African continent and yielded conflicting findings. Consequently, this study investigated the relationship between ISO 14001 EMS Certification and performance of certified firms in Nairobi County, Kenya. Two main research hypotheses were tested. The study applied descriptive, cross sectional research design in a census of 36 firms in Nairobi County, Kenya. Primary data was collected via structured questionnaires and analyzed using descriptive and inferential statistics. The descriptive data indicated general agreement among respondents that implementation of the core ISO 14001 elements in their respective firms satisfied the requirements specified on the questionnaire to a great extent, and that the factors for effective implementation of ISO 14001 were in place in their firms. Firm Performance improvement from ISO 14001 was rated in the range of 10-15\%, though with variation in the ratings obtained. Environmental Policy, Planning, and Implementation and Operation have a positive relationship with Firm Performance, although this is not statistically significant for the element of Planning. Checking and Corrective Action and Management Review in turn have a significant, negative relationship with Firm Performance. The moderated regression analysis showed evidence of positive moderation by Firm Characteristics for Environmental Policy, Checking and Corrective Action, and Management Review, but not for Planning and Implementation and Operation; while the strength of the relationship improved by $8.4 \%$. The study recommends that firms be cognisant of the moderating factors affecting successful implementation of EMSs in their respective industry set ups, and critically assess how these can be addressed at firm level, in order to enhance their ability to benefit from adopting EMSs.
\end{abstract}

Keywords: environmental management system, certification, firm performance, firm characteristics

\section{Introduction}

Modern industrial activities involving manufacturing of goods rely on production methods that trace their origin to the Industrial Revolution period. While the Industrial Revolution delivered many gains to society such as increased productivity in the agricultural and manufacturing sector, breakthrough scientific and technical advances, and general economic growth, this revolution generated multiple environmental hazards such as air and water pollution, global warming, land degradation, loss of biodiversity and depletion of natural resources. The occurrence of these environmental hazards has to date continued to spark a great degree of public outcry, with customers and other stakeholders demanding that industries demonstrate good environmental citizenry by addressing the negative impacts of their activities on the environment. On their part, industries have become increasingly conscious of the importance of the environment as a source of the resources that they depend on for their survival.

In responding to these pressures, industries have employed various mechanisms in an effort to improve their environmental performance. These mechanisms have ranged from reactive approaches based on simple compliance to 
established regulations, to more proactive approaches focused on management of environmental risks and sustainable development (International Institute of Sustainable Development, 2013). Over time, however, compliance based approaches have been found to be ineffective as tools for driving improvements in environmental performance, particularly due to their potential to create unexpected costs for firms. Consequently, there has been a shift towards more proactive approaches for the management of environmental issues. Among the proactive approaches, a widespread practice amongst firms has been the adoption of Environmental Management Systems (EMS). An EMS is an integral part of the overall management system that includes organizational structure, planning, responsibilities, procedures, processes, activities and resources for developing, implementing, achieving, reviewing and maintaining an environmental policy (International Organization for Standardization (ISO), 2004). EMSs provide a structured framework that organizations can use to manage the environmental impacts associated with their products, services and activities, so as to ultimately improve their environmental performance.

The ISO 14001 Environmental Management System Standard, published by the International Organization for Standardization (ISO) in 1996 is the world's most recognized EMS framework. It outlines the requirements that an organization must meet in order for its EMS to be registered or certified to the ISO 14001 EMS standard. The ISO 14001 standard provides a systematic and process driven approach that enables firms to control those aspects of their businesses that have a significant impact on the environment, thereby enhancing their environmental performance. The standard is geared towards incorporating environmental improvement into every aspect of a company's operations, thereby bringing environmental issues into the mainstream of the corporate decision-making process.

The implementation of the ISO 14001 EMS Standard follows the plan-do-check- act (PDCA) cycle developed by Walter Shewhart and Edward Deming (Colceag, Dascălu, Lungu \& Caraiani, 2015). The cycle comprises five core elements: (1) Development of an environmental policy which must highlight three fundamental commitments on prevention of pollution, compliance to legal and other requirements, and continual improvement; (2) Planning of the EMS, whereby the organization identifies its significant environmental aspects and all the legal and other requirements applicable to these aspects, based on which it formulates appropriate environmental objectives, targets and programs for their attainment; (3) Implementation of the EMS, whereby the organization must define the environmental management structure, roles and responsibilities for the operation of the EMS, structure training and awareness programs on the EMS and develop clear communication channels both internally and externally; (4) Checking and corrective action, whereby the organization must carry out routine environmental monitoring and also periodic EMS audits, so as to determine whether the stipulated requirements are being met and ensure continual improvement; (5) Management review of the EMS, in which the organization's Management must assess the suitability, adequacy and effectiveness of the EMS, in relation to the overall goal of improved corporate environmental performance (ISO, 2004; Marsh, 2012).

In terms of demonstrating conformity with the requirements of the ISO 14001 EMS standard, organizations have the option of seeking certification by third party accredited certification auditors or making a self-declaration of conformity with the standard. In the latter option, a company that has implemented ISO 14001 publicly asserts that it conforms to the standard, without the involvement of accredited certification bodies. This option is particularly preferred by small companies which lack adequate resources to obtain third party certification. Many organizations however, opt to seek accredited certification by a third party auditor(s) as an independent confirmation that their EMS meets the requirements of ISO 14001. This option however bears significant cost implications for firms and thus the decision as to the adoption of the ISO 14001 EMS standard will be construed to fall in the category of strategic decisions of the firms. Two aspects of strategic decisions of firms that link with adoption of the ISO 14001 standard entail consideration of the external environment so as to guide adoption of strategic choices that incur costs upon implementation to guarantee returns as viable investments (Hofer \& Schendel, 1978). For firms adopting the ISO 14001 EMS standard, management considers such moves as strategic choices that help in responding to their external environments so as to generate sustainable returns in the foreseeable future. ISO 14001 has been hailed as the world's most successful EMS standard and as at the end of December 2014, 324,148 certificates had been issued in 170 countries worldwide even though the numbers vary across countries, with Africa recording the lowest number. This situation points towards a widespread belief by the international business community in the benefits of attaining ISO 14001 EMS certification.

In Kenya, as is the case in other countries worldwide, the ISO 14001 EMS standard presents an appropriate framework for businesses, particularly those in environmentally sensitive industries such as manufacturing, chemicals, electrical appliances and agriculture, for demonstration of good environmental stewardship to customers and other stakeholders such as suppliers, competitors and regulators. However, the uptake of this standard by Kenyan 
firms has been very low, with only 51 companies having been certified to ISO 14001 as at December 2013, and the number of certified firms dropping to 45 as at December 2014.

\subsection{Research Problem and Objectives}

With the widespread acceptance and popularity of ISO 14001 on the international front, the question that has emerged and perturbed researchers and business people alike has been how certification of firms' EMSs to the ISO 14001 EMS standard contributes to performance. Various researchers around the world have conducted studies analyzing the relationship between ISO 14001 EMS certification and the performance of certified firms. However, the results of their studies have been sharply divided on the exact nature of this relationship. Some researchers such as Bellesi, Lehrer and Tal (2006), Murillo-Luna and Ramón-Solans-Prat (2008), Jacobs, Singhal and Subramanian (2010), Nee and Wahid (2010) and Ferron, Funchal, Nossa and Teixeira (2012) have argued that certification to ISO 14001 yields various benefits in terms of market gains and cost reductions, all of which result in improved firm performance. However, other researchers such as Canon-de-Francia and Garces-Ayerbe (2009), Heras-Saizarbitoria, Molina-Azorin and Dick (2011), Kapasi and Parekh (2011), Paulraj and Jong (2011) and Sigurgeirsdóttir (2014) have presented a divergent opinion, with their findings suggesting that ISO 14001 EMS certification offers little or no value in terms of enhancing the performance of the certified firms. Further, some researchers such as Segarra-Oña, Peiró-Signes, Verma and Miret-Pastor (2012) have suggested that the relationship between ISO 14001 EMS certification and performance is dependent on various firm specific moderating variables such as size, a factor that is suggestive of the resource pool available to the facility.

From a conceptual point of view, it is observed that most of these empirical attempts have not clearly indicated how such an important area of business can be further explained using the extant rich knowledge in organizational studies underpinning strategic decision making in organizations. It is the view of the researchers that the experienced contradictions in empirical findings could be resolved or better explained using the strategic management lens that will consider EMS decisions as strategic choices whose outcomes in firms can be explained using the multidisciplinary literature from organizational studies. Given that the ISO standards are increasingly gaining popularity across the globe where both researchers and managers need to justify investments into their implementation through corresponding firm performance, the strategic perspective so implied needs to be embraced to help researchers extend knowledge on EMS into new geographical locations where little has been documented. In the Kenyan situation, the researchers did not come across any research that specifically examined the link between ISO 14001 EMS certification and performance of firms. This situation, as well as the lack of consensus in the literature from other countries elsewhere on the same aspect, poses a major challenge to decision makers in the industry who would in particular wish to know whether or not the benefits of certification outweigh its costs.

Based on the foregoing, the overall purpose of this study was to examine certification to the ISO 14001 EMS Standard and its contribution to the performance of certified firms. The study focused on firms based in Nairobi County in Kenya, and identified two main objectives. The first objective sought to determine the extent to which the various components of the 14001 EMS (Environmental Policy, Planning, Implementation and Operation, Checking and Corrective Action and Management Review) contribute to the Performance of ISO 14001 certified firms in Nairobi County, Kenya. The second objective of the study sought to determine the moderating effect of Firm Characteristics on the relationship between ISO 14001 EMS certification and Performance of ISO 14001 certified firms in Nairobi County, Kenya.

This research is considered important in various respects. First, the study contributes in terms of bridging the gap in the existing body of research which has to a large extent focused on other countries beyond Kenya, and the entire African region at large. While ISO 14001 has been undertaken in organizations, an integrative perspective that benefits from the diverse literature supporting strategic decision making in organizations has been missing. The current paper presents results of empirical findings that have been investigated and interpreted through an integrated theoretical and conceptual lens that utilizes the multidisciplinary literature in organizational studies informing strategic decision making in organizations. Through this approach, the findings of the study reported provide a vital reference point for scholars who may in future be interested in further advancing on the research on the relationship between ISO 14001 EMS certification and the performance of firms from a strategic point of consideration. Secondly, the findings provide an understanding of the relationship between the core elements of ISO 14001 EMS and firm performance, as well as the influence of firm characteristics on this relationship. Third, the findings of the study provide a basis for more informed decision making by the Management of firms, in considering the strategic decision on whether or not to pursue ISO 14001 EMS certification. 


\section{Literature Review}

\subsection{Theoretical Review}

ISO 14001 EMS standard has its origin in the family of standards developed by ISO for purposes of helping organizations manage their environments. Throughout its history, the elements of the standard have been adopted by organizations at varying degrees with the outcomes in those organizations also varying. A close scrutiny of the pillars of this family of standards indicates that the components have attributes that are best operationalized and implemented as part of organizations' strategic moves. However, in spite of this fact, most of the endeavours to implement the standards have to a great extent failed to appreciate this important link between the ISO 14001 elements and the nature of strategic management decisions. An important source of the informing knowledge towards building the needed bridge is through an examination of relevant theories that scholars have relied on to justify adoption of environmental management systems that point to strategic management aspects. The study reviewed theories postulated by various scholars on the nature of the relationship between environmental proactivity and firm performance. These included the Neoclassical Economists' Perspective and the Stockholder Theory, which present arguments of a negative relationship between environmental proactivity and firm performance; the Stakeholder Theory and Resource Based View, which suggest that environmental proactivity and firm performance are positively related, and the Theory of the Firm Perspective which presents the argument of a neutral relationship between environmental proactivity and firm performance.

The Neoclassical Economists' perspective bases its view of a negative link between corporate social/environmental performance and financial performance on the argument that environmental responsibility forces firms to incur additional costs which are likely to outweigh the resulting profits (Waddock \& Graves, 1997). According to the Neoclassical Economists' Theory, such costs should be borne by other actors such as individuals or the government. The Stockholder Theory by Friedman (1970) is based on the Neoclassical view, and posits that the manager's core obligation is to the owners of the corporation, i.e. the stockholders. The theory argues that this special relationship implies that the firm bears no commitment to non-shareholding stakeholders (Rodin, 2005). The Stockholder Theory cautions that managers may engage in corporate environmental responsibility to further their own social, political, or career agendas at the expense of shareholders, resulting in an agency problem that causes a negative relationship between environmental performance and financial performance. Taking an opposing stand, the Stakeholder Theory by Freeman (1984) argues that managers are obligated to a wider group of stakeholders other than the firm's shareholders. Thus, improved corporate environmental performance will positively affect financial performance (Preston \& O'Bannon, 1997), since attention to environmental issues is viewed favourably by key stakeholders and thus enables a firm to forestall negative responses from them, while projecting a better corporate image and securing their loyalty. The Resource Based View (RBV), in turn bases its proposition of a positive relationship between environmental proactivity and firm performance on competitive advantages derived from development of valuable, inimitable resources and capabilities by firms, in their quest to improve their environmental performance (Hart, 1995; Russo \& Fouts, 1997). In contrast to the theories supporting the view of either a positive or negative link between corporate environmental proactivity and firm performance, the Theory of the Firm Perspective by McWilliams and Siegel (2001) bases its argument of a neutral relationship between these constructs on a framework based on the theory of supply and demand. This theory posits that production of social/environmental performance must be considered from the standpoint of its contribution to shareholder wealth maximization, whereby social/environmental performance should be offered at a level proportionate to the unique demand for social/environmental performance experienced by each firm. Consequently, at equilibrium, firms that engage in environmental responsibility would be equally profitable to those that do not, since firms investing in social/environmental performance would incur higher costs and higher revenues, while firms that do not would have lower costs and lower revenues.

From these diverse theoretical works, it is observed that even though some lay emphasis on the need for organizations to show responsibility on environmental management, others do not support this view, on the basis of the extra cost implications that such initiatives would bear for firms. Thus, due to this consideration of costs vis-à-vis the benefits derived, the concern raised for organizations to exercise responsibility over their environments assumes a strategic dimension. Several scholars articulating characteristics of strategic decisions indicate that they touch on focusing on the environment, planning for the future and the implied costs in the medium and long term periods (Hofer \& Schendel, 1978; Pearce \& Robinson, 1997).

\subsection{ISO 14001 EMS Certification and Firm Performance}

The question of how ISO 14001 EMS certification contributes to firm performance has been in existence for many years with various researchers conducting studies to establish the exact nature of the relationship between these two 
constructs. The study reviewed literature comprising articles that were published after 2005, which utilized ISO 14001 EMS certification as their independent variable, and firm performance as their dependent variable. The review revealed mixed findings, with researchers taking divergent positions on the direction of the relationship between ISO 14001 EMS certification and firm performance.

The proponents of ISO 14001 have claimed that certification of firms' EMSs to this standard delivers a host of benefits to the respective firms. These include reduction in operational costs as a result of reduction of wastes as well as more efficient utilization of energy and material inputs. Other benefits cited include regulatory and insurance cost savings, as well as improved customer and other stakeholder relationships. Further, it has been argued that obtaining certification to ISO 14001 presents additional external benefits such as signalling the firm's commitment to environmental management to its external stakeholders. This in turn results in the creation of a corporate image that enhances the firm's attractiveness to the global market and potential investors, thereby improving its competitiveness, with benefits such as increased market share and sales volumes.

The benefits of signalling environmental commitment through ISO 14001 EMS certification have been investigated in various studies where objective financial data has been utilized. For example, Wahba (2008) investigated the effect of corporate environmental responsibility on firm market value, using ISO 14001 EMS certification to represent corporate environmental responsibility, and Tobin's $q$ ratio to represent firm market value. The study observed a positive and significant effect by Tobin's $q$ ratio on firm market value, and concluded that the market rewards firms for their environmental consciousness. Jacobs, Singhal and Subramanian (2008), in their study which examined the effects of environmental performance on shareholder value through stock market reactions found that announcements of ISO 14001 EMS certifications and philanthropic gifts to environmental causes resulted in significant positive market reaction. Studies by Ferron, Funchal, Nossa and Teixeira (2012) and Jong, Paulraj and Blome (2013), also revealed a positive relationship between ISO 14001 EMS certification and firm profitability. In other studies that have utilized survey based methods, the findings have also led to the same conclusion of a positive relationship between ISO 14001 EMS certification and firm performance. For example, a study by Nee and Wahid (2010) on certified small and medium enterprises in Malaysia established that ISO 14001 had a significant, positive relationship with the operational and business performance of firms. Similar studies by Marjanovic, McLennan and Hamid (2014) in Singapore and Matuszak-Flejszman (2008) in Poland reported benefits such as enhancement of firm competitiveness, increased access to new markets, cost reductions arising from environmental performance improvements such as reduction in wastes, emissions, energy and water consumption, and also increased amounts of recycled wastes.

Other authors have investigated the relationship between ISO 14001 certification and performance of firms but have obtained findings that differ to various extents from those suggesting the existence of a positive relationship between these two constructs. For example, a survey study by Ann, Zailani and Wahid (2006) on ISO 14001 certified firms in Malaysia established that although ISO 14001 certification has a positive impact on some aspects of firm performance namely perceived economic impact, perceived environmental impact and perceived customer satisfaction, it does not enable Management to address the core aspects underlying the firm's positioning in the marketplace, such as reduction of lead-times and costs, and improvement of quality. Another study by Frondel, Krätschel and Zwick (2014) on almost 4200 facilities in seven OECD countries, namely, Canada, France, Germany, Hungary, Japan, Norway, found that EMS implementation without certification had no effect on business performance, indicating that pure EMS implementation does not deliver cost reduction benefits to the firm. On the other hand, the comparatively better performance of facilities with certified EMSs was attributed to the increased sales opportunities arising from the signalling effects of EMS certification.

Researchers such as He, Liu, Lu and Cao (2014) in China, and Sigurgeirsdóttir (2014) in Iceland have suggested that ISO 14001 EMS certification has an insignificant relationship with performance of firms. In the study by He et al. (2014), this was attributed to increases in both costs and sales by similar extents, thereby resulting in their offsetting each other. Similarly, Sigurgeirsdóttir (2014) found that ISO 14001 EMS certification yielded only minor increases in firm operating profits and decreases in operating costs, ultimately resulting in an insignificant relationship between ISO 14001 EMS certification and firm performance. In Spain, a five year longitudinal study by Heras-Saizarbitoria, Molina-Azorin and Dick (2011) on firms both before and after certification did not find any evidence of significant sales and profitability improvements after certification, thereby suggesting the absence of treatment effects from ISO 14001certification. The study also went further to demonstrate the dominance of a selection effect, whereby firms with better prior financial performance tend to pursue ISO 14001 EMS certification. In this regard, the study alluded to the possible existence of reverse causation as had been pointed out in an earlier 
study by King and Lenox in 2001, and suggested that the assertion that ISO 14001 certification enhances financial performance may not hold true in all cases.

In their studies which utilized event study methodology, Canon-de-Francia and Garces-Ayerbe (2009) and Paulraj and Jong (2011) observed a negative effect of ISO 14001 EMS certification announcements on stock performance. In the study by Paulraj and Jong (2011) this outcome was attributed to negative perceptions by investors towards the commitment of resources to ISO 14001 EMS certification, an undertaking that tends to be expensive, and with many benefits that cannot be easily translated to the bottom line of the firm. This, from the investors' perspective, contravenes the fundamental objective of business which is to maximize shareholder wealth through cost minimization and increase in "immediate" profits (Paulraj \& Jong, 2011). On the other hand, the study by Canon -de-Francia and Garces-Ayerbe (2009) cited the same reason for the depressed stock performance but for less polluting and less internationalized firms.

In terms of the relationship between the core elements of ISO 14001 EMS and firm performance, the literature review did not come across any study that specifically examined this aspect. Instead, the studies found focused on exploring the critical success factors affecting organizational success in implementation of ISO 14001 EMS. For example, one such study by Sambasivan and Fei (2008) on the electrical and electronics companies in Malaysia sought to rank four key critical success factors (CSFs) for ISO 14001 EMS implementation, and to identify the benefits arising from adopting this standard. The CSFs were derived from the five core elements of ISO 14001 (i.e. Environmental Policy, Planning, Implementation and Operation, Checking and Corrective Action, and Management Review), and the external and social aspects that trigger adoption of EMSs by firms, such as, government regulations, market pressure, and customer requirements. The study results indicated the critical success factors in order of importance as being: (i) Management Approach, which comprised the ISO 14001 core elements of Environmental Policy, Planning and Management Review, (ii) Organizational Change, consisting of the core element of Implementation and Operation, (iii) Technical Aspects, comprising the core element of Checking and Corrective Action and (iv) External and Social Aspects. The study also reported the benefits of ISO 14001 EMS as being, improvement in company image and reputation, improvement in company processes and profits, improvement in customer loyalty and trust, improvement in staff morale and employer-employee relations.

From this review, it is evident that some of the researches have attempted to show the links between 14001 EMS in general and firm performance while others have examined the elements of ISO 14001 EMS in terms of their importance to the EMS implementation process. None of the researches seem to have used the specific components of the EMS to demonstrate how each relates with the performance of firms. In view of such a silence on areas that the theory demonstrates to have a strategic role, it is of interest to both management and scholars to show how each of the core elements of ISO 14001 EMS are empirically linked to the performance of firms that implement the standard.

\subsection{Influence of Firm Characteristics}

The fact that firm characteristics have potential to influence the relationship between ISO 14001 EMS certification and firm performance has been demonstrated from the results of studies by authors such as Segarra-Oña, Peiró-Signes, and Miret-Pastor (2012), in Spain. In their study, which focused on the Spanish hotel industry, the authors investigated the relationship between certification to the ISO 14001 standard, and generation of economic revenues. The study noted that whereas performance of ISO 14001 certified hotels differed significantly from that of un-certified ones; hotel size, a factor suggestive of the available resource pool, and firm specific factors such as market segment served both played an important moderating role in determining revenues. With reference to the aspect of firm capabilities, Kang, Wipayangkool and Prater (2010) posit that whereas ISO 14001 alone should be able to enhance part of the financial performance of firms, the interplay between ISO 14001 and effective Knowledge Management Capability should trigger substantial improvement in financial performance metrics such as Return on Assets (ROA), stock values, and sales volumes. Darnall (2007) in turn highlights firm internal competencies as a critical factor influencing the relationship between environmental management and firm performance. Additionally, the importance of factors such as firm prior performance is also evident from the earlier reported works of authors such as Heras-Saizarbitoria, Molina-Azorin and Dick (2011) and King and Lenox (2001), who have presented the argument of reverse causation. In this case, more profitable firms tend to better positioned to leverage their financial resources to invest in environmental performance initiatives, thereby enhancing their potential to realize better performance from these undertakings. 


\subsection{Conceptualization and Hypotheses}

Based on the theoretical and empirical literature reviewed in relation to the main research question under investigation, the study developed a conceptual framework presented in Figure 1, which shows the operationalization of the study variables.

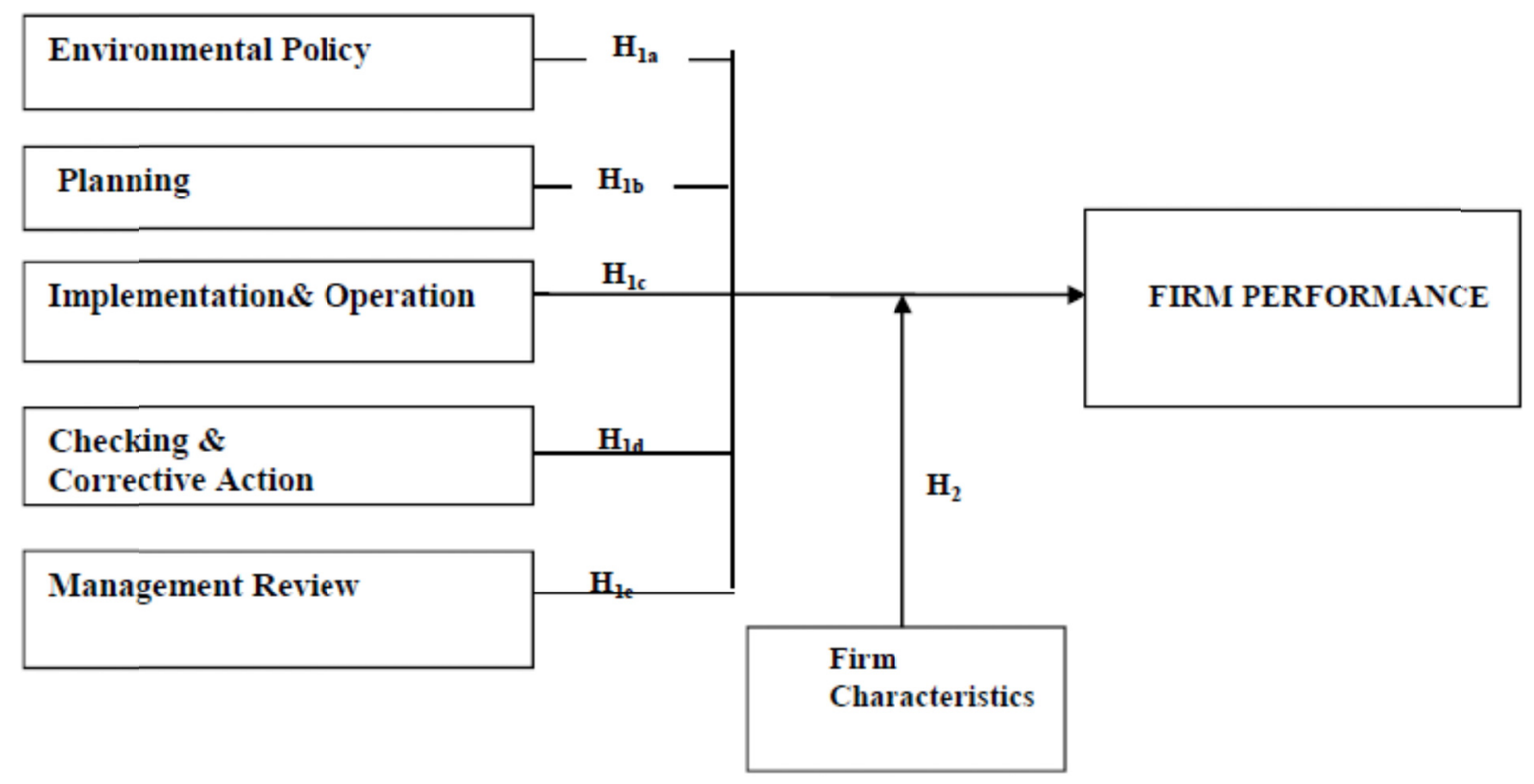

Figure 1. Conceptual framework

From the conceptual framework, two main hypotheses were stated as follows:

Hypothesis One

This was based on the relationship between the five core elements of ISO 14001 EMS and the performance of a firm. Thus hypothesis one was stated:

$\mathrm{H}_{1}$ : There is a significant relationship between the core elements of ISO 14001 EMS and Performance of certified firms in Nairobi County, Kenya. Specifically:

$\mathrm{H}_{1 \mathrm{a}}$ : There is a significant relationship between Environmental Policy and Performance of ISO 14001 certified firms.

$\mathrm{H}_{1 b}$ : There is a significant relationship between Planning of the Environmental Management System and Performance of ISO 14001 certified firms.

$\mathrm{H}_{1 \mathrm{c}}$ : There is a significant relationship between Implementation and Operation of the Environmental Management System and Performance of ISO 14001 certified firms.

$\mathrm{H}_{1 \mathrm{~d}}$ : There is a significant relationship between Checking and Corrective Action in the Environmental Management System and Performance of ISO 14001 certified firms.

$\mathrm{H}_{1 \mathrm{e}}$ : There is a significant relationship between Management Review of the Environmental Management System and Performance of ISO 14001 certified firms.

Hypothesis Two

Even though the core elements of ISO 14001 have a significant relationship with Firm Performance, this relationship is conditioned by the characteristics of each firm. Thus hypothesis two was stated:

$\mathrm{H}_{2}$ : Firm Characteristics have a moderating influence on the relationship between the core elements of ISO 14001 EMS and Firm Performance. 


\section{Methodology}

\subsection{Research Design and Population}

The study utilized a descriptive research design so as to generate information that would enable a conclusion to be drawn on the relationship between ISO 14001 EMS certification and performance of registered firms. The target population for the study comprised all the organizations in Kenya that had been certified to ISO 14001 as at end of December 2013. According to the ISO Survey of 2014 (ISO, n.d.), these firms were 51 in total. The choice of the date of December 2013 was informed by the fact that firms that had been certified by that date would have had ample time to experience the effects of ISO 14001 certification. The list of the 51 firms was obtained from the three certification bodies in Kenya, namely Bureau Veritas (K) Ltd, SGS (K) Ltd and the Kenya Bureau of Standards. Given that the study targeted only firms located in Nairobi County, a total of 36 firms were sampled and a census carried out on them, since the population was small.

\subsection{Data Collection and Analysis}

The study utilized a self-administered questionnaire for collection of primary data. The questionnaire consisted of structured/closed-ended questions that had been designed to address both the general and specific objectives of the study. The questionnaire was pretested prior to the main survey using a sample of 10 ISO Managers to determine its internal consistency, which was then analyzed by means of Cronbach's Alpha. The study adopted a cut-off of 0.7 for the Alpha score. The overall Alpha Coefficient obtained from the analysis of the pretest data exceeded the cut off of 0.7 , indicating that the internal consistency of the questionnaire was strong.

The data generated from the study was quantitative and was analyzed by means of both descriptive and inferential statistics, using the Statistical Package for Social Sciences (SPSS). Descriptive statistics employed in the analysis comprised measures of Central Tendency and dispersion i.e. the mean and standard deviation respectively. Inferential statistics comprised stepwise multiple linear regression analysis, which was used to test the research hypotheses. The regression models used comprised one model for testing the direct relationship between the core elements of ISO 14001 EMS and Firm Performance, and two models for testing the indirect relationship between these constructs, via the moderating variable as guided by the observations guiding the test of statistical moderation by Baron and Kenny (1986), Mackinnon, Lockwood, Hoffman, West and Sheets (2002), and Mackinnon and Fairchild (2009). They provide a stepwise based approach that is statistically modeled using linear regression models as follows:

$$
\begin{array}{cr}
Y=i+a X+\varepsilon_{i} & \text { (Model 1) } \\
Y=i+b M & \text { (Model 2) } \\
Y=i+a X+b M+c X M+\varepsilon_{i} & \text { (Model 3) }
\end{array}
$$

Where

$\boldsymbol{Y}=$ Dependent variable, i.e. Firm performance; $\boldsymbol{X}=$ Independent variable i.e. ISO 14001 EMS certification, whose sub-variables comprise the five core elements of ISO 14001, namely, Environmental Policy, Planning, Implementation and Operation, Checking and Corrective Action, and Management Review; $\boldsymbol{i}=$ Constant Term; $\boldsymbol{a}=$ Main effect of $X$ i.e. effect of $X$ when $M$ is zero; $\boldsymbol{b}=$ Main effect of $M$ i.e. effect of $M$ when $X$ is zero; $\boldsymbol{c}=$ The moderation effect; $\boldsymbol{\varepsilon}_{\boldsymbol{i}}=$ Error term

\section{Findings}

\subsection{Response Rate and Respondents' Characteristics}

The study had targeted a total of 36 firms from Nairobi County which had been awarded ISO 14001 EMS certification by December 2013. A total of 33 firms responded to the questionnaire, representing a response rate of $91.7 \%$. The majority of the survey respondents comprised firms from the Fast Moving Consumer Goods sector which had been in operation for between 31-50 years, and which had a workforce of 301-500 employees. Most survey respondents also held other management system certifications, notably ISO 9001.

\subsection{Descriptive Findings}

The summary of the descriptive analysis data is presented in Table 1. The aggregate mean score values for the variables interpreted according to the scale of the questionnaire show that the different variables were rated at the level of slightly above "Agree" for Environmental Policy, Planning, Implementation and Operation, Checking and Corrective Action, Management Review respectively, and average for Firm Performance. 
Table 1. Summary of descriptive analysis on variables

\begin{tabular}{lccll}
\hline Variable & $\boldsymbol{\alpha}$ Score & No. of Items & Aggregate Mean & Standard Deviation \\
\hline Environmental Policy & 0.877 & 5 & 4.600 & 0.4845 \\
\hline Planning & 0.735 & 5 & 4.7573 & 0.4921 \\
\hline Implementation and Operation & 0.847 & 5 & 4.5500 & 0.6394 \\
\hline Checking and Corrective Action & 0.750 & 5 & 4.5535 & 0.6761 \\
\hline Management Review & 0.808 & 5 & 4.7578 & 0.4333 \\
\hline Firm Characteristics & 0.532 & 5 & 4.3454 & 0.7023 \\
\hline Firm Performance & 0.824 & 6 & 3.1640 & 1.0746 \\
\hline Overall $\boldsymbol{\alpha}$ Score & $\mathbf{0 . 7 7 4}$ & 36 & & \\
\hline
\end{tabular}

\subsection{Results of Hypotheses Tests}

The study tested the two main research hypotheses in two stages. In the first stage, the first five sub hypotheses drawn from hypothesis one tested the direct relationship between the core elements of ISO 14001 EMS, and Firm Performance. In the second stage, hypothesis two tested the indirect relationship between the core elements of ISO 14001 EMS and Firm Performance, via the moderating variable of Firm Characteristics. Table 2 provides the summary of the regression results for this test while Table 3 details the comparison of the regression statistics for the direct and indirect relationship models.

Table 2. Regression test results for direct and indirect relationship between ISO 14001 EMS and firm performance

\begin{tabular}{|c|c|c|c|c|}
\hline \multicolumn{5}{|c|}{ Model 1: $Y=i+a X+\varepsilon_{i}$} \\
\hline Parameter & Value & p-Value & Observation & Conclusion \\
\hline $\mathrm{R}^{2}$ & 0.654 & & $\begin{array}{l}65.4 \% \text { of variation in } \\
\text { performance explained by the } \\
\text { core elements of ISO } 14001 \\
\text { EMS. }\end{array}$ & $\begin{array}{l}\text { Relationship between the core elements } \\
\text { of ISO } 14001 \text { EMS and Firm } \\
\text { Performance is relatively strong }\end{array}$ \\
\hline $\mathrm{F}$ & 9.810 & 0.000 & Regression model is significant & $\begin{array}{l}\text { Regression model is a good predictor of } \\
\text { Firm Performance }\end{array}$ \\
\hline$\beta$ Constant & -0.645 & 0.052 & & \\
\hline $\begin{array}{l}\beta \text { Environmental } \\
\text { Policy }\end{array}$ & 0.369 & 0.010 & $\mathrm{H}_{1 \mathrm{a}}$ is supported. & $\begin{array}{l}\text { There is a Significant, Positive } \\
\text { relationship between Environmental } \\
\text { Policy and Firm Performance. }\end{array}$ \\
\hline$\beta$ Planning & 0.240 & 0.144 & $\mathrm{H}_{1 \mathrm{~b}}$ is not supported. & $\begin{array}{l}\text { There is a Positive relationship between } \\
\text { Planning and Firm Performance that is not } \\
\text { significant }\end{array}$ \\
\hline $\begin{array}{l}\beta \quad \text { Implementation } \\
\text { and Operation }\end{array}$ & 0.585 & 0.000 & $\mathrm{H}_{1 \mathrm{c}}$ is supported. & $\begin{array}{l}\text { There is a Significant, Positive } \\
\text { relationship between Implementation and } \\
\text { Operation and Firm Performance }\end{array}$ \\
\hline $\begin{array}{l}\beta \quad \text { Checking and } \\
\text { Corrective Action }\end{array}$ & -0.602 & 0.001 & $\mathrm{H}_{1 \mathrm{~d}}$ is supported. & $\begin{array}{l}\text { There is a Significant, Negative } \\
\text { relationship between Checking and } \\
\text { Corrective Action and Firm Performance }\end{array}$ \\
\hline $\begin{array}{l}\beta \quad \text { Management } \\
\text { Review }\end{array}$ & -0.287 & 0.038 & $\mathrm{H}_{1 \mathrm{e}}$ is supported. & $\begin{array}{l}\text { There is a Significant, Negative } \\
\text { relationship between Management } \\
\text { Review and Firm Performance }\end{array}$ \\
\hline
\end{tabular}


Model 2: $Y=i+b M$

\begin{tabular}{|c|c|c|}
\hline Parameter & Value & p-Value \\
\hline $\mathrm{R}^{2}$ & 0.143 & \\
\hline $\mathrm{F}$ & 5.170 & 0.030 \\
\hline$\beta$ Constant & -0.651 & 0.036 \\
\hline $\begin{array}{l}\beta \\
\text { Characteristics }\end{array}$ & 0.378 & 0.030 \\
\hline
\end{tabular}

Model 3: $Y=i+a X+b M+c X M+\varepsilon_{i}$

\begin{tabular}{|c|c|c|c|c|}
\hline Parameter & Value & p-Value & Observation & Conclusion \\
\hline $\mathrm{R}^{2}$ & 0.738 & & $\begin{array}{l}73.8 \% \text { of variation in } \\
\text { performance explained by the } \\
\text { moderated regression model. }\end{array}$ & $\begin{array}{l}\text { Strength of the relationship between core } \\
\text { elements of ISO } 14001 \text { and Firm } \\
\text { Performance improves by } 8.4 \%\end{array}$ \\
\hline $\mathrm{F}$ & 11.724 & 0.000 & $\begin{array}{l}\text { Moderating Regression model is } \\
\text { significant }\end{array}$ & $\begin{array}{l}\text { Regression model is a good predictor of } \\
\text { Firm Performance }\end{array}$ \\
\hline$\beta$ Constant & 4.759 & 0.079 & & \\
\hline $\begin{array}{l}\beta \quad \text { Environmental } \\
\text { Policy }\end{array}$ & 0.485 & 0.001 & $\mathrm{H}_{2}$ is supported & $\begin{array}{l}\text { There is a Significant, Positive } \\
\text { relationship between Environmental } \\
\text { Policy and Firm Performance. }\end{array}$ \\
\hline$\beta$ Planning & 0.129 & 0.389 & & $\begin{array}{l}\text { There is a Positive relationship between } \\
\text { Planning and Firm Performance that is not } \\
\text { significant }\end{array}$ \\
\hline $\begin{array}{l}\beta \text { Implementation } \\
\text { and Operation }\end{array}$ & 0.492 & 0.000 & & $\begin{array}{l}\text { There is a Significant, Positive } \\
\text { relationship between Implementation and } \\
\text { Operation and Firm Performance. }\end{array}$ \\
\hline $\begin{array}{l}\beta \quad \text { Checking and } \\
\text { Corrective Action }\end{array}$ & 0.613 & 0.000 & & $\begin{array}{l}\text { There is a Significant, Positive } \\
\text { relationship between Checking and } \\
\text { Corrective Action and Firm Performance. }\end{array}$ \\
\hline $\begin{array}{l}\beta \quad \text { Management } \\
\text { Review }\end{array}$ & 0.172 & 0.174 & & $\begin{array}{l}\text { There is a Positive relationship between } \\
\text { Management Review and Firm } \\
\text { Performance that is not significant. }\end{array}$ \\
\hline $\begin{array}{l}\beta \\
\text { Characteristics }\end{array}$ & 0.337 & 0.009 & & $\begin{array}{l}\text { There is a Significant, Positive } \\
\text { relationship between Firm Characteristics } \\
\text { and Performance. }\end{array}$ \\
\hline
\end{tabular}

Table 3. Comparison of regression statistics for direct and indirect relationship models

\begin{tabular}{llllll}
\hline Parameter & Model 1 & Model 2 & Model 3 & Change & Conclusion \\
\hline $\mathrm{R}^{2}$ & 0.654 & 0.143 & 0.738 & 0.084 & $\begin{array}{l}\text { Strength of the relationship is higher } \\
\text { (Improvement) }\end{array}$ \\
\hline$\beta$ Constant & -0.645 & & 4.759 & 5.404 & Evidence of positive moderation \\
\hline$\beta$ Environmental Policy & 0.369 & & 0.485 & 0.116 & Evidence of positive moderation \\
\hline$\beta$ Planning & 0.240 & & 0.129 & -0.111 & Evidence of negative moderation \\
\hline$\beta$ Implementation and Operation & 0.585 & & 0.492 & -0.093 & Evidence of negative moderation \\
\hline B Checking and Corrective Action & -0.602 & & 0.613 & 1.215 & Evidence of positive moderation \\
\hline$\beta$ Management Review & -0.287 & & 0.172 & 0.459 & Evidence of positive moderation \\
\hline$\beta$ Firm Characteristics & & 0.378 & 0.337 & & \\
\hline
\end{tabular}


From the results of the test on the direct relationship between the core elements of ISO 14001 EMS and Firm Performance, the findings indicate that Planning, Environmental Policy and Implementation and Operation are positively related to Firm Performance while Checking and Corrective action and Management Review are negatively related. Hypotheses $1 \mathrm{a}, 1 \mathrm{c}, 1 \mathrm{~d}$ and $1 \mathrm{e}$ are supported while $1 \mathrm{~b}$ is not. When the moderating factor of Firm Characteristics is introduced into the relationship, the strength of the relationship between the core elements of ISO 14001 and Firm Performance improves by $8.4 \%$. The coefficients of the independent variables change as: Environmental Policy, Checking and Corrective Action and Management Review significantly increase while that of Planning and Implementation and Operation decline. Thus using the criteria provided by Baron and Kenny (1986), Mackinnon et.al (2002), and Mackinnon and Fairchild (2009), the results show evidence of a moderating influence of Firm Characteristics on the relationship between the core elements of ISO 14001 EMS and Firm Performance.

\section{Discussions and Implications for Theory}

The study was designed to establish the effect of ISO 14001 EMS certification on performance of certified firms in Nairobi County in Kenya. The study was conceptualized on the background that EMS constitutes a strategic decision in firms that choose to adopt its components as a way of relating with their environments. The results of the descriptive analysis indicate high aggregate mean scores of above 4, and low standard deviations of below 1 for all the core elements of ISO 14001. This indicates that the respondents were generally in agreement that the implementation of these elements in their respective firms satisfied the requirements specified on the questionnaire to a great extent. The same was noted for the moderating variable of Firm Characteristics, indicating respondents being in agreement that the requisite factors for effective implementation of ISO14001 EMS i.e. consistently strong financial performance, availability of innovative environmental technology, pro-activity in trying out new environmental technologies and excellent environmental management, know-how and experience, were in place in their respective firms. Contrastingly, for Firm Performance, the aggregate mean of 3.1640 indicates the respondents rating the extent of performance improvement from ISO 14001 EMS certification within the range 10-15\%. The high standard deviation (1.07463) indicates disparity in respondents' opinions on the extent of performance improvement in their respective firms that was attributable to ISO 14001 EMS certification. This variability could be explained by the results of a study by Nishitani (2011) which found that the outcomes resulting from EMS implementation were dependent on the industries and as such, not all firms could derive competitive advantages from adopting EMSs. Other researchers such as Segarra-Oña, Peiró-Signes, and Miret-Pastor (2012) and Darnall (2007) have pointed out that performance can also vary across various firms, depending on the effect of moderating factors such as firm size and availability of complementary resources and capabilities. Such factors would therefore be expected to cause differences in performance outcomes, even for firms within the same sector or industry.

The results from testing of hypothesis $\mathrm{H}_{1 \mathrm{a}} \mathrm{H}_{1 \mathrm{~b}}$ and $\mathrm{H}_{1 \mathrm{c}}$ indicate a positive relationship between the core elements of Environmental Policy, Planning, Implementation and Operation, and the dependent variable of Firm Performance. This could be attributed to the criticality of the role played by these elements within the EMS, and their somewhat more direct contribution to the success of the EMS. Specifically, the Environmental Policy forms the cornerstone upon which the entire EMS is established. Planning in turn is crucial as it delineates the strategy upon which the entire EMS is established. It is in the Planning phase that all relevant environmental information is compiled and assessed, thereby allowing for the formulation of performance criteria, goals and objectives and goals for the EMS. The importance of the Implementation and Operation element on the other hand, emanates from the fact that it constitutes the phase in which the environmental strategy is translated into action, and entails mobilization of all resources required for the implementation of the EMS. Effective deployment of the Implementation and Operation phase is therefore a crucial determinant of the EMS's ability to deliver the desired results.

Regarding the statistical significance of the effects of the core elements of ISO 14001 on Firm Performance, a contrasting situation is observed whereby the effect of Planning, unlike that of Environmental Policy and Implementation and Operation is not significant. This could suggest that the role of Planning is not as crucial as that of Environmental Policy, and Implementation and Operation. The element of Planning serves as a link between Environmental Policy and Implementation and Operation. Without a clearly defined and realistic vision being underscored in the Environmental Policy, the EMS Planning process would be a wasted effort owing to lack of a guiding principle or ideal. Similarly, the EMS Plan, no matter how well articulated, would be inconsequential to Firm Performance, unless backed up by a comprehensive and well coordinated implementation effort. The lower statistical significance of Planning in comparison to Implementation and Operation also lends support to the arguments of various scholars such as Flood, Dromgoole, Carroll and Gordon (2000) and Kaplan and Norton (2000), on strategy execution being more important in determining organizational success, as compared to strategy planning. 
The outcome of hypotheses $\mathrm{H}_{1 \mathrm{~d}}$ and $\mathrm{H}_{1 \mathrm{e}}$ whereby the elements of Checking and Corrective Action and Management Review are negatively related with Firm Performance could be attributed to the fact that these two elements are only focused on the evaluation of the EMS. The activities undertaken in the Checking and Corrective Action and Management Review phases do not in themselves result in improved performance. Instead, it is the extent to which Top Management acts on the information generated from these phases to institute actions for the improvement of the EMS that determines its ultimate performance. The results on statistical significance whereby the effect of Checking and Corrective Action on Firm Performance is more significant than that of Management Review could be explained on the basis of the interrelationship between these two elements. The key activities undertaken in the Checking and Corrective Action phase comprise environmental monitoring and measurement, evaluation of compliance, internal audits and resolution of non conformities. The information generated in this phase constitutes a vital input to the Management Review forum, which in turn evaluates the suitability and adequacy of the EMS and makes adjustments as necessary to the plans for the EMS. Thus, without the information from the Checking and Corrective Action phase, the Management Review process would not be comprehensive and would not serve its core purpose of continual improvement of the EMS.

The outcome of the second hypothesis $\mathrm{H}_{2}$ focusing on the moderating influence of Firm Characteristics shows a positive moderating effect for the elements of Environmental Policy, Checking and Corrective Action, and Management Review. This result could be explained from previous researches which have highlighted the crucial role played by various firm characteristics in the EMS. For example, the formulation of the Environmental Policy and Management Review are both tasks whose responsibility is principally vested on the Top Management of the firm. Without a committed Top Management team, these tasks would not be properly executed, and this would negatively affect the EMS. The positive impact of Top Management Commitment on the EMS has been cited in the works of various authors such as Morovati-Sharifabadi, Sadrabadi and Namakshenas-Jahromi (2014), Hessami, Golsefid-Alavi, Shekaf, and Mavi (2012), and Sambasivan and Fei (2008). For the element of Checking and Corrective Action, firm characteristics such as the availability of appropriate technology to enable precise environmental measurements to be made as well as adequate expertise for effective execution of the internal audit process would be a significant positive contributor to the EMS.

The findings on the test of the second hypothesis can also be interpreted in terms of the increase in the value of the constant by 5.404 points, indicating transformation of the relationship between the core elements of ISO 14001 EMS and Firm Performance to a strongly positive one. The result of a positive relationship between ISO 14001 EMS and Firm Performance, as exhibited in the adjusted regression model, is in agreement with both previous empirical work, and a section of the extant theoretical work underpinning strategic management practice. In terms of previous empirical work, the finding is consistent with those of previous researchers such as Bellesi, Lehrer and Tal (2006), Murillo-Luna and Ramón-Solans-Prat (2008), Jacobs, Singhal and Subramanian (2010), Nee and Wahid (2010) and Ferron, Funchal, Nossa and Teixeira (2012), who found evidence of a positive relationship between these two constructs. In terms of the theoretical framework underpinning strategic management practice, the finding on the existence of a positive relationship between ISO 14001 EMS certification and Firm Performance provides support to the postulates of the Stakeholder Theory and Resource Based View. However, the finding contrasts the Neoclassical Economists' Perspective and Stockholder Theory, which present arguments of a negative link between environmental proactivity and firm performance.

The change in the value of $\mathrm{R}^{2}$ from 0.654 in the direct relationship model, to 0.738 in the indirect relationship model, indicates a stronger explanatory power by $8.4 \%$, when the moderating factor is introduced. This indicates that the moderating factor enhances the strength of the relationship between the core elements of ISO 14001 EMS and Firm Performance. The finding lends support to the works of authors such as Segarra-Ona and Miret-Pastor (2012), Heras-Saizarbitoria, Molina-Azorin and Dick (2011), and King and Lenox (2001) whose works alluded to the moderating role of factors such as firm size and prior performance. Similarly, Darnall (2007) stresses the important role of internal firm competencies in influencing the relationship between environmental management and firm performance while Hart (1995) emphasizes the role of complementary process innovation capabilities in enabling a firm to adhere to the ISO 14001 requirement on continual improvement.

The results for the test of the second hypothesis show a negative moderating effect for the core elements of Planning and Implementation and Operation. This paper offers an explanation of this situation based on the fact that the two elements represent the most difficult and time consuming phase of the EMS, irrespective of the specific characteristics of the firm. For example, in the Planning phase, the process of identification of environmental aspects and their associated impacts, as well as the relevant environmental legislation tends to be an arduous task that would pose a challenge to smaller organizations which may lack the necessary expertise to carry out this task. For larger organizations, more time and resources would have to be invested to complete this activity because of their more complex settings and also the extent of consultation required before deciding on the eventual design of the EMS. 
Likewise, in the Implementation and Operation phase, activities such as the identification of staff EMS training needs, development of the requisite EMS documentation and emergency preparedness plans would pose a challenge to both small and large organizations for the same reasons.

\section{Conclusion and Recommendations}

The purpose of this study was to examine how certification to the ISO 14001 Environmental Management System (EMS) standard contributes to the performance of certified firms in Nairobi County in Kenya. This purpose was further broken down into five sub-objectives whose focus was to determine the extent to which each of the five core elements of the ISO 14001 EMS standard contributes to the performance of certified firms. Additionally, the study sought to establish how Firm Characteristics moderate the relationship between ISO 14001 EMS certification and Firm Performance. Based on the results presented, the study makes three conclusions.

First, with respect to the contribution of the ISO 14001 Standard to firm performance, the study concludes that overall, in the context of certified firms within Nairobi County, Kenya, there exists a significant relationship between the core elements of ISO 14001 EMS and performance of certified firms, which is enhanced upon consideration of the moderating variable of Firm Characteristics. These characteristics comprise factors that contribute to the effectiveness of implementation of the ISO 14001 EMS standard, such as, the level of Top Management commitment, the financial base of the firm as well as the availability of an adequate pool of complementary resources and capabilities in environmental management. Therefore, firms need to be cognisant of the role of firm characteristics in successful implementation of EMSs in their respective industry set ups, and critically assess how they can be addressed at firm level, in order to enhance their ability to benefit from investments in EMSs. Secondly, in spite of the persistent uncertainty regarding the benefits of environmental proactivity, the ISO 14001 EMS standard has a positive contribution towards the performance of certified firms. Thirdly, in terms of the literature informing strategic management as a branch of organizational studies, adoption of ISO 14001 is a strategic decision area since the phenomenon it brings about in organizations is explainable using the multidisciplinary based literature underpinning strategic management decisions in organizations.

In drawing the conclusions presented, the study was not without limitations. Specifically, three key limitations were encountered which could be addressed in future research. First, the study only focused on firms located within Nairobi County Kenya. Thus, the findings may not be generalizable across the country. Replication of the research in other regions within Kenya is therefore recommended so as to complement the findings from the current study and provide information that would enable a conclusion to be drawn on the effects of this standard on a nationwide scale. Secondly, the study did not address the challenges faced by organizations in implementation of the ISO 14001 standard. This aspect would provide an interesting area for future research work as it would provide information on the factors that hinder organizations from effectively implementing the standard, and thus affect their ability to derive the benefits that arise from its adoption.

Lastly, in exploring the nature of the relationship between ISO 14001 EMS and firm performance, the study failed to consider the country's macro and micro environmental factors and implications for theories such as the Institutional Theory. When applied to the natural environment, it would be expected, under the Institutional Theory that the influence of institutional pressures such as regulatory and social pressures should result in homogeneous outcomes from firms, such as the adoption of standardized environmental management systems such as ISO 14001. However, a body of literature available argues that varied implementation tends to occur depending on the firms' own internal culture, norms and values and needs. This varied implementation consequently leads to different performance outcomes (Yin \& Schmeidler, 2009). Consequently, it would be of particular interest for future research to investigate how the interplay of forces from the macro and micro environment influence the implementation of the ISO 14001 EMS by organizations and how this ultimately affects their performance outcomes.

\section{References}

Ann, G. E., Zailani, S., \& Wahid, N. A. (2006). A study on the impact of environmental management system (EMS) certification towards firms' performance in Malaysia. Management of Environmental Quality, 17(1), 73-93. http://dx.doi.org/10.1108/14777830610639459

Baron, R.M., \& Kenny, D.A. (1986). The moderator-mediator variable distinction in social psychological research: Conceptual, strategic and statistical considerations. Journal of Personality and Social Psychology, 51, 1173-1182. http://dx.doi.org/10.1037/0022-3514.51.6.1173

Bellesi, F., Lehrer, D., \& Tal, A. (2006). Comparative Advantage: The Impact of ISO 14001 environmental certification on exports. Environmental Science and Technology, 39(7), 1943-53.

Cañón-de-Francia, J., \& Garcés-Ayerbe, C. (2009). ISO 14001 environmental certification: A sign valued by the market? Environmental and Resource Economics, 44(2), 245-62. http://dx.doi.org/10.1007/s10640-009-9282-8 
Colceag, F., Dascălu, C., Lungu, C., \& Caraiani, C. (2015). Green Accounting Initiatives and Strategies for Sustainable Development. Hershey, PA: IGI Global.

Darnall, N., Jolley, J., \& Ytterhus, B. (2007). Chapter 6. Understanding the relationship between a facility's environmental and financial performance. In N. Johnstone (Ed.), Environmental policy and corporate behaviour (pp. 213-249). Cheltenham: Edward Elgar/OECD.

Ferron, R.T., Funchal, B., Nossa, V., \& Teixeira, J.C. (2012). Is ISO 14001 certification effective? An experimental analysis of firm profitability. Brazilian Administration Review, 9(5), 78-94.

Flood, P.C., Dromgoole, T., Carrol, S.J., \& Gorman, L. (Eds). (2000). Managing strategy implementation: an organizational behaviour perspective. Oxford: Blackwell.

Freeman, E. (1984). Strategic management: a stakeholder approach. Boston: Pitman.

Friedman, M. (1970, September). The Social Responsibility of Business is to Increase its Profits. Corporate Ethics and Corporate Governance, 173-178._http://dx.doi.org/10.1007/978-3-540-70818-6_14

Frondel, M., Krätschell, K., \& Zwick, L. (2014, November). Environmental Management Systems- Does Certification Pay? (Working Paper no.519). http://dx.doi.org/10.4419/86788594

Hart, S. L. (1995). A natural-resource-based view of the firm. Academy of Management Review, 20(4), 986-1014. http://dx.doi.org/10.5465/AMR.1995.9512280033

He, W., Liu, C., Lu, J., \& Cao, J. (2014). Impacts of ISO 14001 adoption on firm performance: Evidence from China. China Economic Review, 32(Issue C), 43-56. http://dx.doi.org/10.1016/j.chieco.2014.11.008

Heras-Saizarbitoria, I., Molina-Azorín, J.F., \& Dick, G.P.M. (2011). ISO 14001 certification and financial performance: selection-effect versus treatment-effect. Journal of Cleaner Production, 19(1), 1-1. http://dx.doi.org/10.1016/j.chieco.2014.11.008

Hessami, H. Z., Golsefid-Alavi, M., Shekaf, S. M., \& Mavi, R. K. (2012). Evaluation of success factors of ISO 14001-Based EMS implementation and ranking the cement industry using the TOPSIS method. Journal of Applied Environmental Biological Science, 2(10), 523-530.

Hofer, C.W., \& Schendel, D. (1978). Strategy Formulation: Analytical Concepts. St. Paul, Minn: West Publishing.

International Institute for Sustainable Development. (2013). The Sustainable Development Journey. Retrieved from http://www.iisd.org/business/sd_journey.aspx

International Organization for Standardization. (2004). ISO 14001: Environmental management systems: requirements with guidance for use. Geneva, Switzerland, International Organization for Standardization.

International Organization for Standardization. (n.d.). The ISO Survey 2013. Retrieved from http://www.iso.org/iso/iso-survey

Jacobs, B.W., Singhal, V.R., \& Subramanian, R. (2010). An empirical investigation of environmental performance and market value of a firm. Journal of Operations Management, 28(5), 430-441. http://dx.doi.org/10.1016/j.jom.2010.01.001

Jong, P., Paulraj, A., \& Blome, C. (2013). The financial impact of ISO 14001 certification: top-line, bottom-line, or both? Journal of Business Ethics, 119(1), 131-149.

Kang, T., Wipayangkool, K., \& Prater, E. (2010, March). Extending the Relationship between ISO 14001 and Financial Performance: A Knowledge Management Perspective. Proceedings of the 41st Southwest Decision Sciences Annual Conference (SWDSI). Dallas, Texas.

Kapasi, F., \& Parekh, N. (2011). The effect of environmental activities on Return on Asset: ISO 14001 effect on manufacturing companies in Sweden (Bachelor's thesis within Economics, Jönköping University). Retrieved from http://www.diva-portal.org/smash/get/diva2:440159/FULLTEXT01.pdf

Kaplan, R. S., \& Norton D.P. (1992). The Balanced Scorecard: measures that drive performance. Harvard Business Review, 70(1), 71-79.

King, A., \& Lenox, M. (2002). Exploring the locus of profitable pollution reduction. Management Science, 48(2), 289-299. http://dx.doi.org/10.1287/mnsc.48.2.289.258

Mackinnon, D.P., \& Fairchild, A.J. (2009). Current directions in mediation analysis. Current Directions in Psychological Science, 18(1), 16-20. http://dx.doi.org/10.1111/j.1467-8721.2009.01598.x

Mackinnon, D.P., Lockwood, C.M., Hoffman, J.M., West, S.G., \& Sheets, V. (2002). A comparison of methods to test mediation and other intervening variable effects. Psychological Methods, 7(1), 83-104. 
http://dx.doi.org/10.1037/1082-989X.7.1.83

Marjanovic, L., Mclennan, P., \& Hamid, A.J. (2014). An investigation of the value proposition for environmental management systems implementation in facility management operations in Singapore. International Journal of Facility Management, $\quad 5(2)$ Retrieved http://ejournals.library.gatech.edu/ijfm/index.php/ijfm/rt/captureCite/118/121

Marsh, J. (2012). ISO 14001: analysis into its strengths and weaknesses, and where potential opportunities for deployment by tomorrow's global business. International Journal of Environmental, Cultural and Social Sustainability, 6(3), 23-36.

Matuszak-Flejszman, A. (2008). Benefits of environmental management system in Polish companies compliant with ISO 14001. Polish Journal of Environmental Studies. 18(3), 411-419.

Mc Williams, A., \& Siegel, D. (2001). Corporate social responsibility: A theory of the firm perspective. Academy of Management Review, 26(1), 117-127. http://dx.doi.org/10.5465/AMR.2001.4011987

Morovati-Sharifabadi., A., Sadrabadi, A.N., \& Namakshenas-Jahromi, M. (2014). Evaluation of the effective factors on organizational success in implementation of environmental management system (EMS): a case of Iranian tile and ceramic industry. International Journal of Economy, Management and Social Sciences, 12(3), 816-821.

Murillo-Luna, J.L., \& Ramón-Solans-Prat, J.C. (2008). Which competitive advantages can firms really obtain from ISO14001 certification?. Journal of Industrial Engineering and Management, 1(2), 104-118. http://dx.doi.org/10.3926/jiem.2008.v1n2.p104-118

Nee, Y.G., \& Wahid, N.A. (2010). The effect of ISO 14001 environmental management system implementation on SMEs Performance: an empirical study in Penang, Malaysia. Journal of Sustainable Development, 3(2), 415-420.

Nishitani, K. (2011). An empirical analysis of the effects on firms' economic performance of implementing environmental management systems. Environmental and Resource Economics, 48(4), 569-586. http://dx.doi.org/10.1007/s10640-010-9404-3

Paulraj, A., \& Jong, P. (2011). The effect of ISO 14001 certification announcements on stock performance. International Journal of Operations \& Production Management, 31(7), 765-788. http://dx.doi.org/10.1108/01443571111144841

Pearce, J.A., \& Robinson, R. B. Jr. (1997). Strategic management: Formulation, implementation and control (6 $6^{\text {th }}$ ed.). Chicago, Irwin.

Preston, L.E., \& O'Bannon, D.P. (1997). The corporate social-financial performance relationship: a typology and analysis. Business and Society, 36(4), 419-429. http://dx.doi.org/10.1177/000765039703600406

Rodin, D. (2005). What's wrong with business ethics? International Social Science Journal, 57(185), 561-571.

Russo, M. V., \& Fouts, P. A. (1997). A resource-based perspective on corporate environmental performance and profitability. Academy of Management Journal, 40(3), 534-559. http://dx.doi.org/10.2307/257052

Sambasivan, M., \& Fei, N. (2008). Evaluation of critical success factors of implementation of ISO 14001 using analytic hierarchy process (AHP): a case study from Malaysia. Journal of Cleaner Production, 16(13), 1424-1433. http://dx.doi.org/10.1016/j.jclepro.2007.08.003

Segarra-Oña, M., Peiró-Signes, A., Verma, R., \& Miret-Pastor, L. (2012). Does environmental certification help the economic performance of hotels? Evidence from the Spanish hotel industry? Cornell Hospitality Quarterly, 53(3), 242-256. http://dx.doi.org/10..1177/1938965512446417

Sigurgeirsdóttir, E.B. (2014). Financial benefit of implementing environmental management system ISO 14001 in Icelandic companies (Published Masters Thesis). Retrieved from http://hdl.handle.net/1946/19396

Waddock, S. A., \& Graves, S. B. (1997). The corporate social performance-financial performance link. Strategic Management Journal, 303-319. http://dx.doi.org/10.1002/(SICI)1097-0266(199704)18:4<303::AID-SMJ869>3.0.CO;2-G

Wahba, H. (2008). Does the market value corporate environmental responsibility? An empirical examination. Corporate Social Responsibility and Environmental Management, 15(2), 89-99. http://dx.doi.org/10.1002/csr.153

Yin, H., \& Schmeidler, P.J. (2009). Why do standardized ISO 14001 environmental management systems lead to heterogeneous environmental outcomes? Business Strategy and the Environment, 18(7), 469-486. http://dx.doi.org/10.1002/bse.629 